\title{
Original article \\ Participation in sports practice and motor competence in preschoolers
}

\author{
Daniel da Rocha Queiroz \\ University of Pernambuco at Recife, Brazil \\ Alessandro Hervaldo Nicolai Ré \\ University of São Paulo, Brazil \\ Rafael dos Santos Henrique \\ Mariana de Sousa Moura \\ Maria Teresa Cattuzzo \\ University of Pernambuco at Recife, Brazil
}

\begin{abstract}
Recent theoretical model suggests that motor competence during early childhood is related to one's current and future health status and that practicing sports seems to be playing a special role in creating such competence. This study aimed to compare performance in gross motor skills among preschoolers participating in regular sports practice (SP) and those not participating (NSP), including comparisons by gender. The study uses secondary data from a population-based study of performance regarding the locomotor and object control skills of preschoolers ( 3 to 5 years old). Preschoolers were assigned to groups SP or NSP, paired by age and sex according to skills: locomotor $(n=54 ; 30$ boys $)$ or object control ( $n=37 ; 17$ boys). Analysis of variance showed that the SP group outperformed the NSP one, and there were gender differences only within SP group. Starting to practice sports during early childhood helps to build motor competence and benefits both genders.
\end{abstract}

Keywords: psychomotor performance, children, sports, physical activity

Resumo - “A participação na prática de esportes e competência motora em crianças pré-escolares." Modelo teórico recente sugere que competência motora na primeira infância está relacionada com o estado de saúde atual e futuro e práticas de esportes parecem ser especiais para tal competência. Este estudo comparou o desempenho motor grosso de pré-escolares participantes em práticas esportivas regulares (PE) com o daqueles não participantes nessas práticas (NPE), incluindo comparações entre gêneros. Dados do desempenho em habilidades locomotoras e de controle de objetos foram retirados de um estudo de base populacional com pré-escolares ( 3 a 5 anos); pré-escolares foram alocados em grupos PE e NPE, pareados por idade e gênero, para as habilidades locomotoras ( $n=54 ; 30$ meninos) ou controle de objetos ( $n=37 ; 17$ meninos). Análise de variância mostrou que o grupo PE foi melhor que o NPE; houve diferenças entre gêneros somente no grupo NPE. Práticas esportivas, já durante a primeira infância, contribuem para a competência motora, beneficiando ambos os gêneros.

Palavras-chave: desempenho psicomotor, crianças, esportes, atividade física

Resumen- - "La participación en la práctica del deporte y la competencia motriz en niños en edad preescolar." Modelo teórico reciente sugiere que la competencia motriz en la primera infancia está relacionada con el estado de salud actual y futuro; las prácticas deportivas parecen ser especial para dicha competencia. Este estudio comparó el desempeño motor bruto de los niños en edad preescolar que participan en las prácticas deportivas regulares (PD) con los que no participan (NPD), incluyendo comparaciones de género. Se tomaron los datos de desempeño en habilidades locomotoras y control objeto de estudio basado en la población con los niños en edad preescolar (3-5 años); los niños se dividieron en grupos PD y NPD, emparejados por edad y género, según las habilidades locomotoras ( $n=54,30$ hombres) o de control de objetos ( $n=37,17$ varones). El análisis de varianza mostró que el grupo de PD fue mejor que NPD, hubo diferencias entre los géneros en el grupo NPD. Las prácticas deportivas desde la infancia, contribuyen a la competencia motriz, en beneficio de ambos géneros.

Palabras clave: desempeño psicomotor, niños, deportes, actividad física 


\section{Introduction}

There are plenty of studies reporting that sedentary behavior is a major contributor to death and disability from non-communicable diseases worldwide, and that competence to perform motor skills may be one factor determining participation in physical activities (Haga, 2008; Stodden et al., 2008). Children with poor motor competence are more likely to adopt a sedentary behavior throughout life (Hardy, King, Farrell, Macniven, \& Howlett, 2010).

During childhood, motor competence is considered the ability to perform fundamental motor skills with proficiency (Stodden et al., 2008) and it forms the basis for future participation in sports and physical activities that require specialized movements (Clark, 2005; Clark, 2007; Stodden et al., 2008). If fundamental motor skills are not properly acquired, a child may face a proficiency barrier that can limit his or her performance and ability to learn new movements and, hence, hindering engagement in physical activities and sports (Clark, 2007).

The influence of physical activity and sports in motor competence of children during infancy has been observed in a number of investigations. Sports during middle childhood has a positive effect on locomotor and/or object control skills (Brauner \& Valentini, 2009; Foweather, McWhannell, Henaghan, Lees, \& Stratton, 2008; Krebs et al., 2010; Ripka, Mascarenhas, Hreczuck, Luz, \& Afonso, 2009), as does dance programs (Souza, Berleze, \& Valentini, 2008). These findings agree with the theoretical approach of Stodden et al. (2008), who suggest the existence of an emerging relationship between the development of motor skill competence and physical activity over time.

As a subcategory of leisure-time physical activity, practicing sport can be characterized as involving organized practical sessions specific to a sport (Vandorpe et al., 2012) which may provide opportunities to be physically active as well as favoring psychosocial development and the acquisition of life skills, such as cooperation, discipline, leadership and self-control (FraserThomas \& Côté, 2006; Malina, 2009). Sports are one way of increasing the amount of time spent on moderate to vigorous physical activities (Wickel \& Eisenmann, 2007) and have the potential to prevent cardiovascular problems and obesity in children (Nelson et al., 2011; Malina, 2009). Sports may also pose a challenge for motor control and coordination and such conditions are critical for the acquisition of motor skills (Guadagnoli \& Lee, 2004; Lee, Swinnen, \& Serrien, 1994). Studies have generally shown a positive association between practicing sport and motor competence in children aged 5 to 12 years (D'Hondt et al., 2013; Fransen et al., 2012; Vandorpe et al., 2012).

It is clear that nowadays plenty of opportunities to engage in sports are available for young children. Private schools, clubs and community offer sports such as swimming, martial arts, soccer and dance for children since preschool age. However, there are scarce data on the influence of sport on motor development during early childhood, despite the fact that this period is one of the most crucial stages in human motor development (Knudsen, 2004; Malina, Bouchard, \& Bar-Or, 2004; Vandorpe et al., 2012).

Furthermore, it remains unclear whether gender has an influence on motor competence in childhood. Some studies comparing the motor performance of children have shown similarities between genders (Brauner \& Valentini, 2009; Hume et al., 2008), but some found boys to have somewhat superior skills (Afonso et al., 2009; Brauner \& Valentini, 2009; Carvalhal \& Vasconcelos-Raposo, 2007; Hardy et al., 2010) while others found girls to perform better (Cliff, Okely, Smith, \& McKeen, 2009; Van Beurden, Zask, Barnett, $\&$ Dietrich, 2002). In view of these results, gender is still a relevant variable in the investigation of motor competence.

This study, therefore, aims to investigate possible differences in gross motor skills among preschoolers aged 3 to 5 years who participate regularly in sports practices (SP) and preschoolers of the same age from the same region who do not (NSP), including comparisons between genders.

\section{Methods}

Using a cross-sectional design, the present study analyzed secondary data from a large-scale longitudinal project titled "Longitudinal Study of the Health and Wellbeing of Children of Preschool Age" (Estudo longitudinal de observação da saúde e bem-estar da criança em idade pré-escolar - ELOS -Pre). Permission for the study was granted by the local ethics committee (CEP 097/10; CAAE - 0096.0.097.000-10) and informed written consent was obtained from all parents/ guardians. The target population consisted of children aged three to five years, from 27 public and private schools proportionally distributed in six political administrative regions of Recife (PE - Brazil). Participants were selected from ELOS-Pre using a cluster sampling multiple stages technique. Initially, schools were selected randomly from an alphabetically ordered list. If a school failed to provide written authorization for participating in the study, it was replaced by a previous school from the list. From each selected school, all regularly enrolled children were invited to participate in the study upon parents/guardians signing a consent form. Assessments took place between August and November 2010.

For the purposes of the present study, the children were divided into two groups based on their participation in sports practices. One group had professionally-oriented sports practices (SP), while the other had no regular involvement in sports (NSP). The criterion for assigning the groups was based on parents' information, which was completed via a population-based questionnaire (ELOS-Pre). ELOS-Pre provided socio-demographic information about the child (such as age and date of birth) and about participation in sports, using the following questions: a) Does your son/daughter practice sports in a professionally supervised setting (including dance and martial arts)? and b) If your son/daughter does participate regularly in a sport, answer what is the type of activity, how many times per week and how long does each session last.

A child was included in the SP group if he or she practiced sports for at least two hours per week as part of a professionally supervised program. Of the 393 children examined for locomotor skills, 54 (30 boys) met the criteria for the SP group and of the 344 children who completed the object control skills test, 37 (17 boys) met the same criteria and were included in the 
Table 1. Sample size $(n)$, mean of age and standard deviation (SD) in months of the preschoolers boys and girls who performed locomotor and object control subtests in the sports practice (SP) and no sports practice (NSP) groups.

\begin{tabular}{|c|c|c|c|c|c|c|}
\hline & \multicolumn{3}{|c|}{ Sports practice } & \multicolumn{3}{|c|}{ No sports practice } \\
\hline & Boys & Girls & Total & Boys & Girls & Total \\
\hline Locomotor skills (n) & 30 & 24 & 54 & 30 & 24 & 54 \\
\hline Age in months/mean (SD) & $60.3(8.0)$ & $59.5(9.7)$ & $60.0(8.7)$ & $60.8(7.9)$ & $57.6(8.0)$ & $59.4(8.1)$ \\
\hline Object control skills (n) & 17 & 20 & 37 & 17 & 20 & 37 \\
\hline Age in months/mean (SD) & $60.3(8.4)$ & $61.6(7.7)$ & $60.9(7.9)$ & $60.6(8.6)$ & $60.9(7.5)$ & $60.7(7.9)$ \\
\hline
\end{tabular}

SP group. The pairing technique (Sampieri, Collado, \& Lucio, 2007) was applied to form the NSP group. Each child from the SP group was thus matched with one from the NSP group, according to gender, age in months (with a maximum variation of six months) and school location. If more than one child met the criteria for inclusion in the NSP group, a random selection was carried out using a sweepstakes tool (www.randomizer.org). There was no statistical difference between the ages of the groups $(p \geq 0.05)$ (Table 1).

All subjects were videotaped performing the Test of Gross Motor Development -2 (TGMD-2) (Ulrich, 2000) which is an instrument designed to assess locomotor (running, skipping, hopping, leaping, horizontal jumping and sliding) and object control skills (striking a stationary ball, stationary dribbling, kicking, catching, overhand and underhand throwing). The TGMD-2 validity and reliability indices for Brazilian children were determined by Valentini (2012). Children's performances were videotaped with a digital camera (Cyber-Shot DSC-H20, 10.1 Megapixel) and their recordings were played-back using the video player Media Player Classic (free download) in slow motion.

Children's performance was rated according to the checklist criteria established in the TGMD-2 (Ulrich, 2000). A score 1 meant successful performance and 0 , failure; the total score was the sum of two trials for each skill. Two raters were suitably trained to apply and decode the test and there was an acceptable level of agreement between the observers (Thomas, Nelson, \& Silverman, 2007) of 0.87 .

When requirements for parametric statistics were met, two-way analyses of variance were performed with groups (SP vs NSP) as a between-individuals variable and gender (male vs female) as a within-individual variable. Tukey's HSD post -hoc procedures were used to test significance. Kruskal-Wallis nonparametric tests were also used to assess the differences when the data did not meet the parametric tests' requirement. Statistical significance was assumed at $p \leq .05$ and the effect size $(E S)$ was also calculated. All statistical analyses were conducted using SPSS (SPSS 10.0 for Windows).

\section{Results}

In general, the SP group performed better than the NSP group. For locomotor skills, the SP group performed better at sliding $(H=10.97, p<.01 ; E S=0.68)$ and on the locomotor subtest score $(H=9.91, p<.01 ; E S=0.64)$. For object control skills, the SP group performed better on the object control subtest score $(H=5.07, p<.05 ; E S=0.58)$ (Tables 2 and 3$)$.

Boys in the SP group performed better in the hopping task $(H=4.10, p<.05 ; E S=0.57)$ and in the locomotor subtest score $(H=6.79, p<.01 ; E S=0.74)$ than boys in the NSP group. In object control skills, the SP group performed better at striking a stationary ball $(H=4.19, p<.05 ; E S=0.79)$ than the NSP group.

Girls from the SP group performed better in the sliding task $(H=9.31, p<.01 ; E S=1.02)$, underhand throwing $(H=5.57$, $p<.05 ; E S=0.84)$ and in the object control subtest score $(H=$ $4.53, p<.05 ; E S=0.74)$ when compared to those from the NSP group (Tables 2 and 3 ).

Table 2. Mean and standard deviation (SD) from preschoolers boys' and girls' locomotor skills performances in the sports practice (SP) and no sports practice (NSP) groups.

\begin{tabular}{|c|c|c|c|c|c|c|}
\hline \multirow[t]{2}{*}{ Locomotor skills } & \multicolumn{3}{|c|}{ Sports practice $(n=54)$} & \multicolumn{3}{|c|}{ No sports practice $(n=54)$} \\
\hline & $\begin{array}{c}\text { Boys } \\
\text { Mean (SD) }\end{array}$ & $\begin{array}{c}\text { Girls } \\
\text { Mean (SD) }\end{array}$ & $\begin{array}{c}\text { Total } \\
\text { Mean (SD) }\end{array}$ & $\begin{array}{c}\text { Boys } \\
\text { Mean (SD) }\end{array}$ & $\begin{array}{c}\text { Girls } \\
\text { Mean (SD) } \\
\end{array}$ & $\begin{array}{c}\text { Total } \\
\text { Mean (SD) }\end{array}$ \\
\hline Running & $7.1(1.0)$ & $7.3(0.9)$ & $7.2(0.9)$ & $7.4(1.1)$ & $7.2(1.0)$ & $7.3(1.0)$ \\
\hline Galloping & $4.9(1.7)$ & $4.5(1.5)$ & $4.7(1.6)$ & $4.0(1.8)$ & 4.6(1.9) & 4.3(1.9) \\
\hline Hopping & $5.7(2.1)^{\S}$ & $5.3(2.8)$ & $5.5(2.4)$ & $4.4(2.6)^{\S}$ & $5.2(2.6)$ & $4.7(2.6)$ \\
\hline Leaping & $5.4(1.0)$ & $5.3(1.5)$ & $5.4(1.2)$ & $5.1(1.1)$ & $5.0(1.5)$ & $5.1(1.3)$ \\
\hline Horizontal jumping & $3.6(2.7)$ & $3.4(2.0)$ & $3.5(2.4)$ & $2.8(2.2)$ & $2.5(1.7)$ & $2.7(1.9)$ \\
\hline Sliding & $4.8(2.4)$ & $5.1(2.5)^{\dagger}$ & $4.9(2.4)^{*}$ & $3.7(2.4)$ & $2.9(1.9)^{\dagger}$ & $3.4(2.2) *$ \\
\hline Subtest score & $31.4(5.5)^{\S}$ & $30.9(7.2)$ & $31.2(6.3)^{*}$ & $27.4(5.4)^{\S}$ & $27.3(6.2)$ & $27.4(5.7) *$ \\
\hline
\end{tabular}

*Difference between groups, $p<.05 \S$ Difference between boys SP and NSP, $\mathrm{p}<.05$; ${ }^{\dagger}$ Difference between girls SP and NSP, $p<.05$. 
Table 3. Mean and standard deviation (SD) from preschoolers boys' and girls' object control skills performances in the sports practice (SP) and no sports practice (NSP) groups.

\begin{tabular}{|c|c|c|c|c|c|c|}
\hline \multirow[b]{2}{*}{ Object control skills } & \multicolumn{3}{|c|}{ Sports practice $(n=37)$} & \multicolumn{3}{|c|}{ No sports practice $(n=37)$} \\
\hline & $\begin{array}{c}\text { Boys } \\
\text { Mean (SD) }\end{array}$ & $\begin{array}{c}\text { Girls } \\
\text { Mean (SD) }\end{array}$ & $\begin{array}{c}\text { Total } \\
\text { Mean (SD) }\end{array}$ & $\begin{array}{c}\text { Boys } \\
\text { Mean (SD) }\end{array}$ & $\begin{array}{c}\text { Girls } \\
\text { Mean (SD) }\end{array}$ & $\begin{array}{c}\text { Total } \\
\text { Mean (SD) }\end{array}$ \\
\hline Striking a stationary ball & $8.0(1.6)^{\# \S}$ & $6.6(2.0)^{\#}$ & $7.2(2.0)$ & $6.4(2.5)^{\S}$ & $6.2(2.2)$ & $6.3(2.3)$ \\
\hline Stationary dribbling & $2.9(2.1)$ & $2.7(2.3)$ & $2.8(2.2)$ & $2.5(1.9)$ & $2.1(1.2)$ & $2.3(1.6)$ \\
\hline Catching & $3.8(1.3)$ & $3.6(2.2)$ & $3.7(1.8)$ & $3.1(1.3)$ & $3.2(1.9)$ & $3.2(1.6)$ \\
\hline Kicking & $4.8(3.1)$ & $5.4(1.8)$ & $5.1(2.5)$ & $5.2(3.2)$ & $4.6(1.9)$ & $4.9(2.6)$ \\
\hline Overhand throwing & $2.6(2.3)$ & $3.1(2.5)$ & $2.9(2.4)$ & $2.5(2.3)$ & $2.5(1.8)$ & $2.5(2.0)$ \\
\hline Underhand throwing & $2.1(2.0)^{\#}$ & $4.1(2.4)^{\# \dagger}$ & $3.2(2.4)$ & $2.1(1.8)$ & $2.5(1.5)^{\dagger}$ & $2.3(1.6)$ \\
\hline Subtest score & $24.2(6.4)$ & $25.4(7.6)^{\dagger}$ & $24.9(7,0)^{*}$ & $21.8(6.3)$ & $21.1(4.0)^{\dagger}$ & $21.4(5.1) *$ \\
\hline
\end{tabular}

*Difference between groups, $p<.05$; ${ }^{\S}$ Difference between boys SP and NSP, $p<.05$;

${ }^{\dagger}$ Difference between girls SP and NSP, $p<.05$; \#Difference between genders in the SP group, $p<.05$.

Also, boys and girls were compared within their respective groups (SP and NSP). The results showed that, in the SP group, boys were better than girls in striking a stationary ball $(H=$ 5.35, $p<.05 ; E S=0.80)$, and girls were better than boys in the underhand throwing $(H=5.79, p<.05 ; E S=0.92)$. There was no difference between genders in the NSP group.

\section{Discussion}

The aim of this study was to investigate possible differences in gross motor skills among preschool children who participated in regular and professionally-oriented sports and those who did not, including comparisons between genders. We expected that children who practiced sports would be more competent at performing fundamental motor skills than children who did not. This hypothesis was confirmed and, in general, the SP group performed better than the NSP group. When comparing gender, the SP boys performed better than those in the NSP group in several skills (hopping, striking a stationary ball and in the total score for locomotor skills), and the SP girls also performed better than the NSP girls (in sliding, underhand throwing and total object control score). Thus, children aged between 3 and 5 years who practice sports seem to experience significant gains in motor competence, outperforming children who do not have this opportunity.

These findings are in agreement with previous studies in which children participating in sports during middle childhood performed better than those who did not (D'Hondt et al., 2013; Fransen et al., 2012; Ulrich, 1987; Vandorpe et al., 2012). In a pioneering study in this field, Ulrich (1987) used a cross-sectional design to test 5-10-year-old children and the results showed that motor competence was significantly related to participation in sports. In a two-year longitudinal study of the relationship of sports practice and motor competence, Vandorpe et al. (2012) showed that children aged eight years who had consistently practiced sport in their previous two years performed fundamental motor skills better than those who only partially participated in sports. Fransen et al. (2012) showed a positive association between time dedicated to sports and physical fitness and motor competence in children aged 6-12 years. Moreover, these authors found that a greater variety of sports was related to better motor outcomes. D'Hondt et al. (2013) also found positive effects of sport when investigating motor competence and body composition. Their two-year longitudinal study followed 50 overweight or obese children aged 6-10 years and another 50 children with normal weight and the final regression model indicated that both, body composition and practice of sports, affected motor competence. These results for middle childhood indicate that practicing sports is desirable for a full and healthy motor development.

According to the model proposed by Stodden et al. (2008), motor competence and physical activity are related in a dynamic and synergistic way, since proficiency in fundamental movement skills is considered an essential element for involvement in sport and physical activity throughout life. Hence, during early childhood, participation in sports and physical activity directs the development of motor competence. Nevertheless, this relationship is modified in middle and late childhood, when a high level of motor competence is expected for children to engage in physical activities. Seeing sport as a special context for the acquisition of motor skills in young children may thus help to promote long-term adherence to physical activity. Theoretically, improvements in motor competence during early childhood are perpetuated so that, in later years, individuals with good motor competence become involved in a positive engagement in physical activities (Stodden et al. 2008).

Some differences between girls and boys were found within groups. In the case of striking a stationary ball, boys performed better than girls in the SP group; in underhand throwing, also in the SP group, girls were better. The positive influence of sport on motor competence in girls can be verified when the SP girls showed higher performance in the object control task than did the NSP girls. Recent evidence has shown that reduced performance in motor skills showed by girls (Barnett, Van Beurden, Morgan, Brooks \& Beard, 2010; Goodway, Robinson, \& Crowe, 2010; Tucker, 2008) is probably culturally determined (Heath et al. 2012). According to Thomas and French (1985), sociocultural issues probably explain differences that may exist between the motor performance of boys and girls, rather than biological fac- 
tors. Generally speaking, gender differences are the product of the family and sociocultural contexts, where boys are encouraged to practice sports and engage in physical activities that favor the acquisition of motor skills (Garcia, 1994; Hardy et al., 2010).

In addition, the present data did not show differences between boys and girls in the SP group. It seems that, if girls are provided with equivalent opportunities to practice sports as the boys are, the differences in motor competence between genders cease to exist at this age. This is an important finding for health policies that aim to improve the level of physical activity and the practice of sports in the population at large, since early childhood is a critical developmental period for the acquisition of motor skills and the adoption of an active lifestyle throughout the rest of life (Barnett et al., 2010; Stodden et al., 2008; Telama, Yang, Laakso, \& Viikari, 1997).

The context in which children are placed during childhood must promote opportunities to develop motor competence and, consequently, engagement in physical activity and healthy behaviors (Erwin, Woods, Woods, \& Castelli, 2007). From a developmental and dynamic perspective, Smith and Thelen (2003) argued that there is a need to understand the processes that a child's daily activities operate on in his or her development-considering overall achievements as well as individual paths. We suggest that practicing sport can lead to a decline in the differences in motor development between boys and girls during early childhood. Furthermore, children participating in sports would be better prepared to overcome the "proficiency barrier" (Clark, 2007; Seefeldt, 1980) and proceed to the stage of motor skills specific to a context and, therefore, experience the motor development process in a full and healthy way.

In view of this, professionally-oriented programs require further attention. Lemos, Avigo and Barela (2012) compared children in early childhood who had physical education instruction with a teacher trained in the area, and children who engaged in physical activity under the supervision of an ordinary teacher. Their results showed that children with a physical education instruction performed better in object control skills. The authors concluded that, even in early childhood, a developmentally adequate intervention provides gains in motor coordination. Ripka et al. (2009) compared children aged 9 to 10 years who played minivolleyball with those who only took part in physical education lessons and the results also showed enhance performance on the part of the group involved in a specific sport, both in terms of locomotor and object control skills. Souza, Berleze and Valentini (2008), in an interventional study with children enrolled in a dance program, found an improvement in locomotor and object control skills after the intervention, as well as improvements in specific dance skills. Krebs et al. (2010) also found superior locomotor, object control and sport-specific skills (striking, catching and throwing) in children playing handball, compared to children not involved in sports. Therefore, developmentally apropriate sports practice with specific instruction provides gains in motor competence and, according to the present data, it may be possible to achieve such gains even in early chilhood.

The present study did not investigate the specific features of each sport practiced by the children. Tani, Basso and Corrêa's (2012) argue that the practice of sports during childhood should emphasize fundamental motor skills and a combination of them. Addressing a widespread belief connecting early involvement in sports with a greater chance of later athletic process, they argued that care should be taken to ensure that the combination of fundamental skills is not overlooked or replaced by emphasis on a specific sport. The findings of the present study suggest that involvement in activities such as practicing of sports provides gains in motor competence, but it is important to realize that sport practices must be appropriate children's developmental stages.

A number of important limitations of the present study should also be noted. The cross-sectional design limits the assessment of causality in the observed associations, as does the absence of measurements relating to intensity, styles of instruction and type of motor skills emphasized during sports practice. On the other hand, the main strength of the present study is that our results corroborate the theoretical model proposed by Stodden et al. (2008), by suggesting that young (early childhood) children's physical activity might drive their development of motor skill competence.

In conclusion, in this sample, children aged 3 to 5 years participating in sports exhibited a significant advantage in terms of motor competence. The SP boys and girls performed better than their peers in the NSP group. Engaging in developmentally appropriate sports from early childhood onwards may thus have a positive impact on the process of motor learning and long-term adherence to the practice of sports and/or physical activity. In agreement with longitudinal studies involving larger samples, the practice of sport in early childhood may be one way of preventing or recovering of obesity and other diseases associated with a sedentary lifestyle.

\section{References}

Afonso, G. H., Freitas, D. L., Lefevre, J. A., Almeida, M. J., Rodrigues, A. J., \& Maia, J. A. (2009). Desempenho motor . Um estudo normativo e criterial em crianças da Região Autónoma da Madeira, Portugal. Revista Portuguesa de Ciencias do Desporto, 9(2-3), 160-74. doi:10.1080/02701367.2013.814910

Barnett, L. M., Van Beurden, E., Morgan, P. J., Brooks, L. O., \& Beard, J. R. (2010). Gender differences in motor skill proficiency from childhood to adolescence: a longitudinal study. Research quarterly for exercise and sport, 81(2), 162-70. doi:20527301

Brauner, L. M., \& Valentini, N. C. (2009). Análise do desempenho motor de crianças participantes de um programa de atividades físicas. Revista da Educação Física/UEM, 20(2), 205-216. doi: 10.4025/reveducfis.v20i2.6070

Carvalhal, M., \& Vasconcelos-Raposo, J. (2007). Diferenças entre géneros nas habilidades : correr, saltar, lançar e pontapear. Motricidade, 3(3), 44-56. Retrieved from http://www.scielo.oces.mctes. pt/scielo.php?pid=S1646-107X2007000300006\&script=sci arttext

Clark, J. E. (2005). From the Beginning: A Developmental Perspective on Movement and Mobility. Quest, 57(1), 37-45. doi:10.1080/00 336297.2005.10491841

Clark, J. E. (2007). On the problem of motor skill development. Journal of Physical Education Recreation Dance, 78(5), 39-44. Retrieved from http://www.tandfonline.com/doi/pdf/10.1080/07303084.200 7.10598023 
Cliff, D. P., Okely, A. D., Smith, L. M., \& McKeen, K. (2009). Relationships between fundamental movement skills and objectively measured physical activity in preschool children. Pediatric exercise science, 21(4), 436-49. Retrieved from http://ro.uow.edu.au/ edupapers/496/

D’Hondt, E., Deforche, B., Gentier, I., De Bourdeaudhuij, I., Vaeyens, R., Philippaerts, R., \& Lenoir, M. (2013). A longitudinal analysis of gross motor coordination in overweight and obese children versus normal-weight peers. International journal of obesity (2005), 37(1), 61-7. doi:10.1038/ijo.2012.55

Erwin, H. E., Woods, A. M., Woods, M. K., \& Castelli, D. M. (2007). Chapter 6: Children's Environmental Access in Relation to Motor Competence, Physical Activity and Fitness. Journal of Teaching in Physical Education, 26, 404-15. Retrieved from http://journals. humankinetics.com/AcuCustom/Sitename/Documents/DocumentItem/11001.pdf

Fransen, J., Pion, J., Vandendriessche, J., Vandorpe, B., Vaeyens, R., Lenoir, M., \& Philippaerts, R. M. (2012). Differences in physical fitness and gross motor coordination in boys aged 6-12 years specializing in one versus sampling more than one sport. Journal of sports sciences, 30(4), 379-86. doi: 10.1080/02640414.2011.642808

Fraser-Thomas, J., \& Côté, J. (2006). Youth sports: Implementing findings and moving forward with research. Athletic Insight, $8(3)$, 12-27. Retrieved from https://athleticinsight.com/Vol8Iss3/YouthPDF.pdf

Foweather, L., McWhannell, N., Henaghan, J., Lees, A., Stratton, G., \& Batterham, A. M. (2008). Effect of a 9-wk. after-school multiskills club on fundamental movement skill proficiency in 8- to 9-yr.-old children: an exploratory trial 1. Perceptual and Motor Skills, 106(3), 745-54. Retrieved from http://www.ncbi.nlm.nih. gov/pubmed/18712195

Garcia, C. (1994). Gender differences in young children's interactions when learning fundamental motor skills. Research Quarterly for Exercise and Sport, 65(3), 213-25. Retrieved from http://www. ncbi.nlm.nih.gov/pubmed/7973070

Goodway, J. D., Robinson, L. E., \& Crowe, H. (2010). Gender differences in fundamental motor skill development in disadvantaged preschoolers from two geographical regions. Research quarterly for exercise and sport, 81(1), 17-24. doi:10.1080/02701367.201 0.10599624

Guadagnoli, M. A., \& Lee, T. D. (2004). Challenge point: a framework for conceptualizing the effects of various practice conditions in motor learning. Journal of motor behavior, 36(2), 212-24. doi:10.3200/JMBR.36.2.212-224

Haga, M. (2008). The relationship between physical fitness and motor competence in children. Child: care, health and development, 34(3), 329-34. doi: 10.1111/j.1365-2214.2008.00814.x

Hardy, L. L., King, L., Farrell, L., Macniven, R., \& Howlett, S. (2010). Fundamental movement skills among Australian preschool children. Journal of science and medicine in sport / Sports Medicine Australia, 13(5), 503-8. doi:10.1016/j.jsams.2009.05.010

Heath, G. W., Parra, D. C., Sarmiento, O. L., Andersen, L. B., Owen, N., Goenka, S., . . . Brownson, R. C. (2012). Evidence-based intervention in physical activity: lessons from around the world. The lancet, 380, 272-81. doi: 10.1016/S0140-6736(12)60816-2

Hume, C., Okely, A., Bagley, S., Telford, A., Booth, M., Crawford, D., \& Salmon, J. (2008). Does weight status influence associations between children's fundamental movement skills and physical activity? Research quarterly for exercise and sport, 79(2), 158-65. Retrieved from http://www.ncbi.nlm.nih.gov/pubmed/18664040

Knudsen, E. I. (2004). Sensitive periods in the development of the brain and behavior. Journal of Cognitive Neuroscience, 16(8), 1412-25. doi: $10.1162 / 0898929042304796$
Krebs, R. J., De Lucca, M., Ramalho, M. H. S., Santos, J. O. L., Nobre, G. C., \& Triches, J. R. (2010). A contribuição da prática do handebol no desempenho das habilidades motoras amplas de escolares. Cinergis, 11(2), 1-8.

Lee T. D., Swinnen S. P. \& Serrien D. J. (1994). Cognitive Effort and Motor Learning. Quest ,46 3, 328-44. Retrieved from http://www. tandfonline.com/doi/abs/10.1080/00336297.1994.10484130

Lemos, A. G., Avigo, E. L., \& Barela, J. A. (2012). Physical Education in Kindergarten Promotes Fundamental Motor Skill Development. Advances in Physical Education, 02(01), 17-21. Retrieved from http://www.scirp.org/journal/PaperDownload.aspx?DOI=10.4236/ ape.2012.21003

Malina R. M., Bouchard C, \& Bar-Or O. (2004). Motor development. In: Growth maturation and physical activity. 2nd ed. Champaign, IL: Human Kinetics.

Malina, R. M. (2009). Children and adolescents in the sport culture: the overwhelming majority to the select few. Journal of exercise science \& fitness, 7(2), 1-10. Retrieved from http://scholar.google. com/scholar?hl=en\&btnG $=$ Search \& $\mathrm{q}=$ intitle:CHILDREN + AND+ADOLESCENTS+IN+THE+SPORT+CULTURE:+THE+OVERWHELMING+MAJORITY+TO+THE+SELECT+FEW\#0

Nelson, T. F., Stovitz, S. D., Thomas, M., LaVoi, N. M., Bauer, K. W., \& Neumark-Sztainer, D. (2011). Do youth sports prevent pediatric obesity? A systematic review and commentary. Current sports medicine reports, 10(6), 360-70. doi: 10.1249/JSR.0b013e$318237 \mathrm{bf} 74$

Ripka, W. L., Mascarenhas, L. P. G., Hreczuck, D. V., da Luz, T. G. R., \& Afonso, C.A. (2009). Comparative study of the performance of children who practice and children who do not practice minivolleyball. Fitness \& Performance Journal, 8(6), 412-16. doi: 10.3900/fpj.8.6.412.e

Smith, L. B., \& Thelen, E. (2003). Development as a dynamic system. Trends in Cognitive Sciences, 7(8), 343-48. doi: 10.1016/S13646613(03)00156-6

Sampieri, R. H., Collado, C. F., \& Lucio, P. B. (2007). Metodologia de pesquisa (3nd ed.). São Paulo: Mcgraw-Hill.

Seefeldt, V. (1980). Developmental motor patterns: Implications for elementary school physical education. In C. Nadeau, W. Holliwell, K. Newell, \& G. Roberts (Eds.), Psychology of motor behavior and sport (pp. 314-323). Champaign, IL: Human Kinetics.

Souza, M. C. De, Berleze, A., \& Valentini, N. C. (2008). Efeitos de um programa de educação pelo esporte no domínio das habilidades motoras fundamentais e especializadas: ênfase na dança. Revista da Educação Física/UEM, 19(4), 509-19. doi: 10.4025/reveducfis. v19i4.5254

Stodden, D. F., Goodway, J. D., Langendorfer, S. J., Roberton, M. A., Rudisill, M. E., Garcia, C., \& Garcia, L. E. (2008). A Developmental Perspective on the Role of Motor Skill Competence in Physical Activity: An Emergent Relationship. Quest, 60(2), 290-306. doi: 10.1080/00336297.2008.10483582

Tani, G., Basso, L., \& Corrêa, U. C. (2012). O ensino do esporte para crianças e jovens: considerações sobre uma fase do processo de desenvolvimento motor esquecida. Revista brasileira de educação física e esporte, 26(2), 339-50. doi: 10.1590/S180755092012000200015

Telama, R., Yang, X., Laakso, L., \& Viikari, J. (1997). Physical activity in childhood and adolescence as predictor of physical activity in young adulthood. American journal of preventive medicine, 13 (4): 31723. Retrieved from http://www.ncbi.nlm.nih.gov/pubmed/9236971

Thomas, J. R., \& French, K. E. (1985). Gender differences across age in motor performance: A meta-analysis. Psychological bulletin, 98(2), 260-82. Retrieved from http://www.ncbi.nlm.nih.gov/ pubmed/3295748 
Thomas, J. R., Nelson, J. K., \& Silverman, S. J. (2007). Métodos de pesquisa em atividade física. (5. ed). Porto Alegre, RS: Artmed.

Tucker, P. (2008). The physical activity levels of preschool-aged children: A systematic review. Early Childhood Research Quarterly, 23(4), 547-58. doi: 10.1016/j.ecresq.2008.08.005

Ulrich, B. D. (1987). Perceptions of physical competence, motor competence, and participation in organized sport: Their interrelationships in young children. Research Quarterly for Exercise and Sport, 58(1), 57-67. doi: 10.1080/02701367.1987.10605421

Ulrich, D. A. (2000). Test of gross motor development: examiner's manual (2nd ed.). Austin, TX: Pro-ed.

Valentini, N. C. (2012). Validity and reliability of the TGMD-2 for Brazilian children. Journal of motor behavior, 44(4), 275-80. doi: 10.1080/00222895.2012.700967

Van Beurden, E., Zask, a, Barnett, L. M., \& Dietrich, U. C. (2002). Fundamental movement skills--how do primary school children perform? The "Move it Groove it" program in rural Australia. Journal of science and medicine in sport / Sports Medicine Australia, 5(3), 244-52. Retrieved from http://www.sciencedirect.com/ science/article/pii/S144024400280010X

Vandorpe, B., Vandendriessche, J., Vaeyens, R., Pion, J., Matthys, S., Lefevre, J., . . Lenoir, M. (2012). Relationship between sports participation and the level of motor coordination in childhood: a longitudinal approach. Journal of science and medicine in sport / Sports Medicine Australia, 15(3), 220-5. doi: 10.1016/j. jsams.2011.09.006

Wickel, E. E., \& Eisenmann, J. C. (2007). Contribution of youth sport to total daily physical activity among 6-to 12-yr-old boys. Medicine and science in sports and exercise, 39(9), 1493-500. doi: 10.1249/ mss.0b013e318093f56a

\section{Authors' note}

Daniel da Rocha Queiroz (http://lattes.cnpq.br/5673831264022461; efdanielrocha@live.com) and Mariana de Sousa Moura (http://lattes. cnpq.br/9763922048139755; marimoura10@hotmail.com) are with the Research Group on Human Motor Behavior and Health, School of Physical Education, University of Pernambuco, Recife.

Alessandro Hervaldo Nicolai Ré, PhD (http://lattes.cnpq. br/7867709528880946; alehnre@usp.br) is with the Graduate Program in Physical Activity Sciences, School of Arts, Sciences and Humanities, University of São Paulo, São Paulo, Brazil

Rafael dos Santos Henrique (http://lattes.cnpq.br/1308420348718829; rdshenrique@hotmail.com) and Maria Teresa Cattuzzo, PhD (http:// lattes.cnpq.br/9733224936509206; mtcattuzzo@hotmail.com) are with the Research Group on Human Motor Behavior and Health, School of Physical Education, University of Pernambuco, Recife, and with the Graduate Associate Program in Physical Education, University of Pernambuco/Federal University of Paraiba, Brazil.

\section{Mailing address:}

Maria Teresa Cattuzzo. School of Physical Education, University of Pernambuco, Campus HUOC. Rua Arnóbio Marques, 310, Santo Amaro. Recife, PE. CEP: 50.100-130. Phone/fax: (81) 3183-3354. E-mail: mtcattuzzo@hotmail.com

\section{Acknowledgments:}

* Partial results of this paper were presented in poster at the Annual Conference of North American Society for the Psychology of Sport and Physical Activity - NASPSPA - Honolulu, Havaii, Jun, 2012. Funding source: Scientific Initiation Scholarship, Brazilian National Council for Science and Technology (CNPq/UPE) (Daniel da Rocha Queiroz) and Pernambuco State Foundation for Science and Technology (FACEPE, process n. ACE-0056-4.09/12 - Maria Teresa Cattuzzo).

Manuscript received on March 8, 2013

Manuscript accepted on August 25, 2013

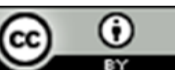

